\title{
Application of PS-InSAR Method for the Land Subsidence Analysis Using StaMPS (Case Study : Gresik Regency)
}

\author{
Rizki Fahrudin Ulin, Muhammad Taufik, and Ira Mutiara Anjasmara
}

\begin{abstract}
Land Subsudence often occurs in various regions around the world, especially big cities and coastal areas. The poor impact of land subsidence may the destruction of a region's infrastructure which caused by excessive water taking for industrial use and existing soil forming structures in the area. Therefore, it is necessary to find various inventions with the aim to mitigate natural disasters accurately. Along with the development of technology, then used adequate technology that has wide area capability. The selection of PS-InSAR method based on Radar becomes the best solution because it has good accuracy and decrease the decorrelation effect. The method used by PSInSAR in the process of land subsidence in Gresik Regency using StaMPS at the same time with the decrease of ground level between $-49.35 \mathrm{~mm} /$ year to $54,95 \mathrm{~mm} /$ year. Bungah Sub-district has the maximum value from the period before May 2015 to January 2016.
\end{abstract}

Keywords-

\section{INTRODUCTION}

Land subsidence processes that occurred in several big cities in Indonesia, especially in coastal areas. Conditions in coastal areas are particularly vulnerable because of the rockforming structure which is very risky both from land and sea. In addition to natural factors, non-natural factors also and in the process of land subsidence [1]. Gresik city is the one of the city of Industry and dense settlements have the characteristics of the rock-forming structure that is identical to Semarang and Surabaya. Manyar and Bungah district area has rock-forming structure that is identical to the northern part of the city of Surabaya. The geographical position is located close to the coast as well as the area of the CBD (Center Bussiness District) makes the development and growth to be very fast. It can be seen with the increasing development and large-scale industrial activities such as Semen Gresik, Gresik Housing New Town, and Condominium in Prambangan area. This directly and indirectly have a negative impact on the surrounding environment.

Analysis of the amount of land subsidence rate can be determined based on the results of the count which has a significant value. Viewed from the standpoint of science of geodesy and geomatics, the lower the soil surface can be detected through a reference point to changes in the vertical

Rizki Fahrudin Ulin, Muhammad Taufik, and Ira Mutiara Anjasmara are with Department of Geomatics Engineering, Institut Teknologi Sepuluh Nopember, Surabaya, 60111, Indonesia. E-mail: ira@geodesy.its.ac.id. position. Therefore, we need a study to analyze the value changes continuously and covers a large area and the time is fast and efficient.

Application of PS-InSAR method included in MTI (Multi Temporal InSAR) is a right step to assess an area experiencing land subsidence. The main principle of PSInSAR technique was to use observational data multitemporal SAR image in a long time span to detect potential points coherence. Dots PS (Permanent scatterer) is generally in the form of solid objects in the earth's surface into a natural reflector coherent relative to the dimension of time. PS distribution points and the difference phase values for each individual point further analyzed using PS-InSAR method using StaMPS algorithm (Stanford Method for Persistent Scatterers) [2].

The majority of developed countries are already using SAR sensor technology as the imaging sensor. Indonesia is slowly started to develop a SAR sensor. Although pennggunaan and development of this system is not completely perfect compared to other countries that already have research several years ago, but this step as a good start for long-term use and innovation.

In this experiment, PS-InSAR method in the study area is located in Gresik Regency. The treatment used in this study is the application of PS-InSAR technique to determine the distribution of the points PS (Permanent scatterer). From the results of such processing will produce a potential area of land subsidence in Gresik regency to get an analysis of the areas experiencing land subsidence high and low values.

\section{MethodolOGY}

\section{A. Study Area and Data}

The location of this research is in Gresik Regency located in East Java Province at the coordinates 112 $21^{\prime} 57.4^{\prime \prime}$ $112^{\circ} 40^{\prime} 38.8^{\prime \prime}$ East Longitude and 6 $6^{\circ} 0^{\prime} 29.2^{\prime \prime}$ - 7²4'30.2" South Latitude. Acquisition data used in for supporting this research were 13 set Sentinel (Level 1A) Single Look Complex (SLC) Imagery.

\section{B. Data Processing}

1. Pre-processing.

In the pre-processing stage, this is the SAR image data already in the form of Interferogram Subwath (IW) and Single Look Complex (SLC). The image used for PS analysis is $\mathrm{HH}$ or VV polarization. Data required at least 8 images however, ESA recommends to use more than 20 images. 
Furthermore, will be the stage Read Product, TOPSAR-Split and Apply Orbit File. Selection of one of the 3 Sub-swaths present on SLC Sentinel-1 products. The selection of this sub- swath purpose to focus the research area and speed up image processing time on SNAP compared to the combined 3 Sub-swaths.

2. Backgeocoding.

In the co-registration processing of two or more complex images, the second image (slave image) is processed / manipulated to resemble the master image and also register the image pair in the same orbital frame. Backgeocoding stage is the SLC image registration step on PS- InSAR processing. Backgeocoding is used because the slave data to be used is multipledata. At this stage, the image already has orbit data. In the Backgeocoding process, the most optimal master image obtained from InSAR Stack Overview should be placed at the top of the ProductSet-Reader.

3. Deburst.

TOPSAR-Debrurst to trace the burst of the azimuth and range into one whole image. Deburst is done because the Sentinel-1 series satellite recording mode uses subswath and burst systems, resulting in an inter-burst gap that must be corrected before the interferometry process continues.

4. Interferogram Formation.

Interferogram stage is performed for phase difference between slave image and master image. In addition, at this stage the value can be known coherence value between images.

5. Tophographics

Phase Removal. In this phase, topographic phase reduction using external DEM. To calculate deformation models on DinSAR method using mathematical models count as follows [3]:

$$
\Delta \varphi=\Delta \varphi_{\text {topo }}+\Delta \varphi_{\text {defo }}+\Delta \varphi_{\text {atm }}+\Delta \varphi_{\text {orb }}
$$

During this processes, simulations of observational geometry parameters were observed. DEM (Digital Elevation Model) SRTM (Shuttle Radar Topography Mission) and Precise Orbit are used as input data so that the interferogram phase can be modeled carefully. The two coordinate system relationships between the master image and the slave image are obtained from the bonding points together on the surface of the earth. So that will be done co-registration process on both images.

\section{StaMPS.}

(Stanford Method for Persistent Scatterers) is a algorithm package that implements an InSAR persistent scatterer (PS) method developed to work even in terrains devoid of manmade structures and/or undergoing non-steady deformation as shown the process below [4]:

a. Loading PS Candidate

StaMPS algorithm can only be done on Matlab with Ubuntu operating system. Converts the data into the formats required for PS processing and stores them in matlab workspaces.

b. Estimate Phase Noise
This is an iterative step that estimates the phase noise value for each candidate pixel in every interferogram.

c. PS Weeding

Pixels selected in the previous step are weeded, dropping those that are due to signal contribution from neighbouring ground resolution elements and those deemed too noisy. Data for the selected pixels are stored in new workspaces.

d. Phase correction

The wrapped phase of the selected pixels is corrected for spatially-uncorrelated look angle (DEM) error. At the end of this step the patches are merged.

e. Phase unwrapping In this phase, the image generated from the interferogram process is still in units of radians (angular phase units) with a range of values $-\pi$ to $\pi$. In the unwrap process it is also a process of eliminating aliasing errors (shifts in high-frequency seismic waves to be lower) of a noise. To find out the magnitude of the deformation calculations of the displacement formulas of the earth's surface along the line of sight sensor (LOS) [5] i.e :

$$
\begin{array}{ll}
\Delta \emptyset_{d n}=\frac{4 \pi \Delta R}{\lambda} & \\
\text { Details: } & \\
\lambda & \text { : Sentinel-1A imagery wavelength } \\
\Delta \emptyset_{d n} & \text { : Value of phase difference } \\
R & \text { : Distance wavelength }
\end{array}
$$

f. Estimate spatially-correlated look angle error Spatially-uncorrelated look angle (SULA) error was calculated in Step 3 and removed in Step 5. In Step 7, spatially-correlated look angle (SCLA) error is calculated which is due almost exclusively to spatiallycorrelated DEM error (this includes error in the DEM itself, and incorrect mapping of the DEM into radar coordinates). Master atmosphere and orbit error (AOE) phase is estimated simultaneously.

\section{Result AND DISCUSSION}

\section{A. Interferogram Result}

Processing of 13 set Sentinel 1-A radar image data in Gresik Regency using PS-InSAR method to find offset and computation area. Depending on the differences in the PSInSAR methodology applied, final results will be obtained (PS density and location). PS-InSAR with StaMPS is better than when applied to areas with non-linear deformation.

The result of interferogram phase image (Figure 1) on radar coordinate system that has been removed tophography effect using DEM SRTM 30 meter.

\section{B. Baseline Perpendicular}

Shown in Figure 2.

\section{Experiment Result}

The analysis result is land deformation of the district and presented as vector file. The land subsidence is overlaid on basic map as shown in Figure 3. 
IPTEK Journal of Proceedings Series No. (2) (2019), ISSN (2354-6026)

The $3^{\text {rd }}$ Geomatics International Conference 2018

July $12^{\text {th }} 2018$, Institut Teknologi Sepuluh Nopember, Surabaya, Indonesia

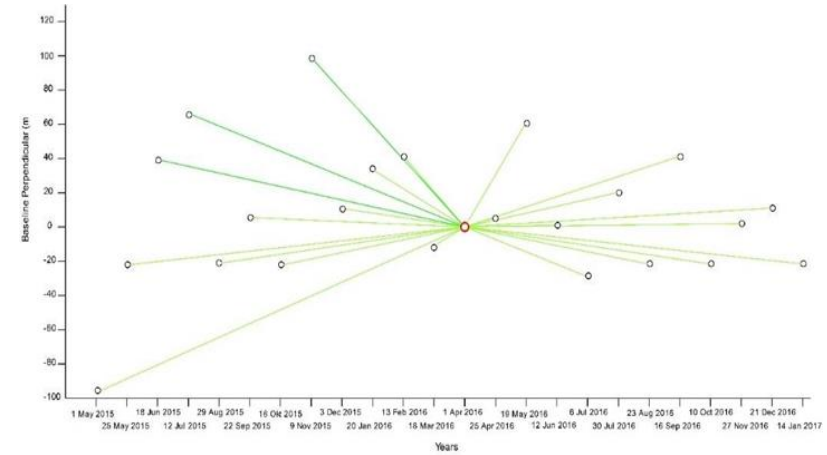

Figure 2. Baseline temporal and baseline perpendicular.

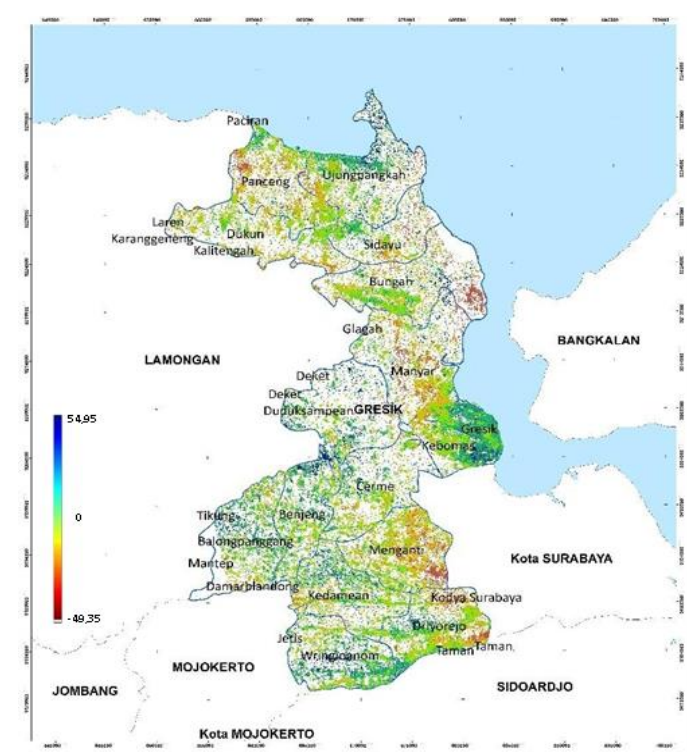

Figure 3. Velocity map of land subsidence in Gresik Regency.

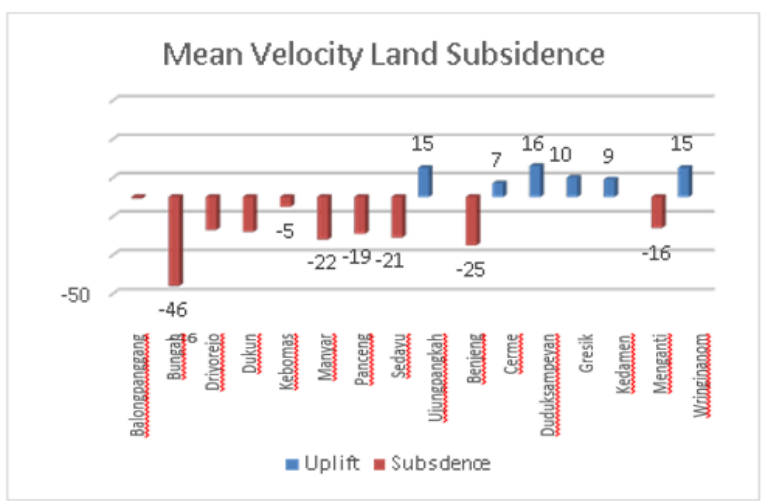

Figure 4. Mean velocity Land Subsidence in Gresik Regency.

The results of PS-InSAR processing showed that there was occur land subsidence in 6 district such as Panceng, Ujungpangkah, Sedayu, Bungah, Manyar and Menganti. The highest averaged displacement occurs in Bungah district that reaches $-49,35 \mathrm{~mm} /$ year. Mean velocity of land Subsidence these Regency is presented in Diagram on Figure 4.

\section{ANALYSIS}

Based on results of radar data processing using PS-InSAR method and arrangement Identification of Geology showed that the District Bungah have land subsidence level higher than the average of other districts, amounting to $-49.35 \mathrm{~mm} /$ year. This suggests that the risk of the impact of land subsidence in the District Bungah higher forming the geological structure of rocks that are Alluvial the form of loose sediment that is transported to another place or not being around the parent rock-sized grains of sand and clay. Furthermore, heavy vehicle loads with excessive tonnage also have an effect to the land subsidence.

Gresik regency is dominated by alluvial soil types. It becomes one factor of displacement in this area which alluvial sediment gives contribution of the displacement because of its characteristic [6]. This is supported by the character of the area north coast (Pantura) eroded and seawater intrusion. It is also exacerbated by the cultivated area is built directly adjacent to the shoreline regardless coastal border that should be free of buildings.

\section{CONCLUSSION}

It has been demonstrated that PS InSAR technique is applicable for $\mathrm{mm}$ scale surface deformation monitoring especially in Gresik Regency. By analyzing data set of SENTINEL images covering the Gresik Regency, significant subsidence of up to $-49 \mathrm{~mm} /$ year has been detected between May 2015 - February 2016. To get the best accuracy and precision of data, another Multitemporal InSAR method is needed. The deformation estimates relate well with results from an independent study and geodetic measurements.

\section{ACKNOWLEDGMENT}

Author thanks to Bandung Geological Agency for the support of data and guidance during this research.

\section{REFERENCES}

[1] A. Ferretti et al., "Submillimeter Accuracy of InSAR Time Series: Experimental Validation," IEEE Trans. Geosci. Remote Sens., vol. 45, no. 5, pp. 1142-1153, May 2007.

[2] R. F. Hanssen, Radar Interferometry, vol. 2. Dordrecht: Springer Netherlands, 2001.

[3] A. Hooper, D. Bekaert, and K. Spaans, "StaMPS/MTI Manual," 2013.

[4] A. H. Nga, H. Changa, L. D. Gea, C. Rizosa, and M. Omurab, "Radar Interferometry For Ground Subsidence Monitoring Using Alos Palsar Data." 2008.

[5] A. Bayhaqi, C. M. A. Dungga, and C. M. A. Dungga, "Distribusi butiran sedimen di pantai Dalegan, Gresik, Jawa Timur," DEPIK, vol. 4, no. 3, Dec. 2015

[6] Z. Abidin, D. F. Kurniawan, and M. F. E. Purnomo, "Analisis Dan Simulasi Parameter Radar Terhadap Performansi Synthetic Aperture Radar Pada Tahap Awal Pencitraan Sensor Radar," J. Mhs. TEUB, vol. 2, no. 3, 2014. 